\title{
Documentation of cervical cytological findings in Çankırı population
}

\author{
Çankırı popülasyonunda servikal sitolojik bulguların dökümantasyonu \\ Yasemin Yuyucu Karabulut*, Yasemin Dölek, Nazmiye Kurşun
}

Pathology Laboratory (Y. Y. Karabulut, MD, Y. Dölek, MD), Çankırı State Hospital, TR-18200 Çankırı, Department of Biostatistics (Bsc N. Kurşun, MD), Ankara University School of Medicine, TR-06100 Ankara

\begin{abstract}
Aim. Cervical cancer is one of the most common female malignancy with high mortality rates in developing countries. Our purpose is to present cervical cytologic abnormalities and the detection rate of epithelial abnormalities by cervical cytology (CC). Method. A total of 8972 conventional pap smear tests collected between August 2010 and August 2012 from Çankırı State Hospital were retrospectively analyzed and results were based on the 2001 Bethesda system. Results. Total of $129(1.4 \%)$ cases had epithelial abnormalities. The numbers and rates of epithelial abnormalities were as the followings: Atypical squamous cell of undetermined significance (ASCUS; $\mathrm{n}=75$ [0.8\%]); atypical squamous cell suspicious for high-grade squamous intraepithelial lesion (ASC$\mathrm{H} ; \mathrm{n}=10[0.11 \%]$ ); atypical glandular cell of undetermined significance (AGUS; $\mathrm{n}=8$ [0.08\%]); low- grade squamous intraepithelial lesion (LSIL; $n=22$ [0.24\%]); high-grade squamous intraepithelial lesion (HSIL; $n=14$ [0.15\%]). Conclusion. The prevelence of cervical cytological abnormality in our study was $1.4 \%$ and the most of them were diagnosed as atypical squamous cell of undetermined significance (ASCUS). Our results partly correspond with the studies that were carried out on the large amounts of Turkish population.
\end{abstract}

Keywords: Cervical cancer, cytology, PAP smear

\section{Özet}

Amaç. Serviks kanseri gelişmekte olan ülkelerde kadınlarda yüksek mortalite oranına sahip en sık görülen malignitedir. Çalışmadaki amacımız Çankırı popülasyonunda servikal sitoloji materyallerinde epitelyal anormalliklerin saptanması ve dökümante edilmesidir. Yöntem. Çalışmada Çankırı Devlet Hastanesinde 2010-2012 ağustos tarihleri arasında toplanmış 8972 servikal pap smear retrospektif olarak 2001 Bethesda sistemi esas alınarak değerlendirilmiştir. Bulgular. Toplam 129 vakada $(\% 1,4)$ epitelyal anormalite izlenmiş, bunların 75 'inde $(\% 0,8)$ önemi belirlenemeyen atipik skuamöz hücreler (ASCUS), 10'unda $(\% 0,11)$ yüksek gradeli atipik intraepitelial lezyon şüpheli atipik skuamöz hücreler (ASC-H), 8'inde $(\% 0,08)$ önemi belirlenemeyen atipik glandüler hücreler (AGUS), 22'sinde $(\% 0,24)$ düşük dereceli skuamöz intraepitelyal lezyon (LSIL), 14'ünde $(\% 0,15)$ yüksek dereceli skuamöz intraepitelyal lezyon (HSIL) saptanmıştır. Sonuç. Çalışmamızda servikal sitolojik anormalite prevalansı \%1,4 olarak bulunmuş, bunlar arasında en yüksek oranı önemi belirlenemeyen atipik skuamoz hücrelerin (ASCUS) oluşturduğu saptanmıştır. Sonuçlar Türkiye genelinde daha geniş popülasyonda yapılan mevcut çalışmalarla kısmen örtüşmektedir.

Anahtar sözcükler: Servikal kanser, sitoloji, PAP smear

Geliş tarihi/Received: August 23, 2012; Kabul tarihi/Accepted: October 12, 2012

\section{*Corresponding author:}

Dr. Yasemin Yuyucu Karabulut, Patoloji Laboratuvarı, Çankırı Devlet Hastanesi, TR-18200 Çankırı. E-mail: yykarabulut@yahoo.com.tr 


\section{Introduction}

Cervical cancer is a leading cause of cancer- related death among woman in developing countries, with up to $80 \%$ of patients presenting with advanced disease [1]. The five-year survival is $50 \%$ in developing countries where it is $66 \%$ in developed ones. All over the world, estimated new cases of cervical (uterine cervix) cancer was 493000 and deaths were 274000 in 2002 [2]. The impact of cervical cytology (CC) screening has been demonstrated by steadily reduced rates of incidence and mortality due to invasive cervical cancer in the developed countries over the last decades. In the past 60 years, the mortality from cervical cancer has decreased 70 to $80 \%$ in developed countries. The incidence was decreased from 32/100 000 in 1940's to 8.3/100 000 in 1980. The Pap smear test is a simple, non-invasive, and a cost-effective method for the diagnosis of cervical and vaginal precancerous, cancerous lesions [3]. According to a study made by the International Agency for Research on Cancer in 2002, the cervical cancer incidence rate in Turkey was 4.5/100 000, it was estimated to encounter 1364 new cervical cancer cases and 726 of the reported deaths were associated with cervical cancer in the same year [2]. In 2003, the results of studies performed by the Turkish Ministry of Health, department of cancer control in eight cities were published [3]. This study showed that cervical cancer ranks the $10^{\text {th }}$ among all women's cancers and its incidence rate is 4.76/100 000 [3]. Similar results were found throughout Europe. Nearly four million cervical screening tests are performed every year in the United Kingdom and the age-standardized incidence and mortality rates for cervical cancer were 9 and 3.7 per 100.000, respectively [4]. There are some differences between Western and Eastern Europe. Every year, nearly 13000 women were diagnosed as cervical cancer in the West, whereas the number was higher in the Eastern Europe (31 000) and more than half of these women were lost due to the cervical cancer $[2,5]$.

Our purpose is to present the cervical cytological abnormalities in the Turkish population in Çankırı and the detection rate of epithelial abnormalities by CC.

\section{Material and methods}

A total number of 8972 conventional pap smear tests were collected between August 2010 and August 2012 from the Çankırı State Hospital which has the unique pathology laboratory in Çankırı and the results were retrospectively analyzed. Conventional samples (CC) were collected and smeared into the slide and immediately fixed with polyethylene glycol. The samples were evaluated by two different pathologists. The results were assessed as satisfactory and unsatisfactory. Satisfactory results were based on the 2001 Bethesda system and subdivided as "negative" (including "atypia, favors reactive"), "squamous cell atypia" (atypical squamous cells of undetermined significance [ASCUS] and atypical squamous cells, cannot exclude high-grade lesions [ASC-H]), "atypical glandular cells" (AGUS), "low-grade squamous intraepithelial lesion" (LSIL), "highgrade squamous intraepithelial lesion" (HSIL), "squamous cell carcinoma" (SCC), and "adenocarcinoma." The statistical analyses were performed by SPSS software 15.0 statistical program.

\section{Results}

A total number of 8972 samples were retrospectively analyzed. The mean age of the participants was $44 \pm 11.28$ years with the range of 18 to 100 years. Cytological findings of the smear results are listed in Table 1 . These data show that the unsatisfactory rate for the $\mathrm{CC}$ technique was $8.8 \%(\mathrm{n}=794)$. The main causes for $\mathrm{CC}$ inadequacy were sample obscured by red blood cells and inflammation. Benign cytology results were seen in 8043 $(89.6 \%)$ of the samples. The most common reported benign result was chronic cervicitis with 5386 cases (60\% of all samples). The numbers and rates of other normal results detected by $\mathrm{CC}$ were as the followings, respectively: Normal benign results, $\mathrm{n}=1537$ (17.1\%); atrophy, $\mathrm{n}=1120$ (12.5\%) (Figure 1a). A total number of $129(1.4 \%)$ cases had epithelial abnormalities. The numbers and rates of epithelial abnormalities were as the 
follows: ASCUS ( $\mathrm{n}=75 / 0.8 \%$ ) (Figure 1b); ASC-H ( $\mathrm{n}=10 / 0.11 \%)$; AGUS ( $\mathrm{n}=8 / 0.08 \%)$; LSIL ( $\mathrm{n}=22 / 0.24 \%$ ) (Figure 1c); HSIL ( $\mathrm{n}=14 / 0.15 \%$ ) (Figure 1d). We did not determine any $\mathrm{SCC}$ cases $(\mathrm{n}=0 / 0.0 \%)$.

Table 1. Cytological findings of 8972 conventional smear samples.

\begin{tabular}{lll}
\hline \multicolumn{3}{l}{ CC numbers } \\
\hline Total & 8972 & $(100 \%)$ \\
Satisfactory & 8178 & $(91.2 \%)$ \\
Unsatisfactory & 794 & $(8.8 \%)$ \\
Normal smear results & 1537 & $(17.1 \%)$ \\
ASCUS & 75 & $(0.8 \%)$ \\
ASC-H & 10 & $(0.11 \%)$ \\
LSIL & 22 & $(0.24 \%)$ \\
HSIL & 14 & $(0.15 \%)$ \\
AGUS & 8 & $(0.08 \%)$ \\
SCC & 0 & $(0 \%)$ \\
\hline ASCUS: Atypica)
\end{tabular}

ASCUS: Atypical squamous cells of undetermined significance, ASC-H: Atypical squamous cells, cannot exclude high-grade lesions, AGUS: Atypical glandular cells, LSIL: Low-grade squamous intraepithelial lesion, HSIL: High-grade squamous intraepithelial lesion, SCC: squamous cell carcinoma.

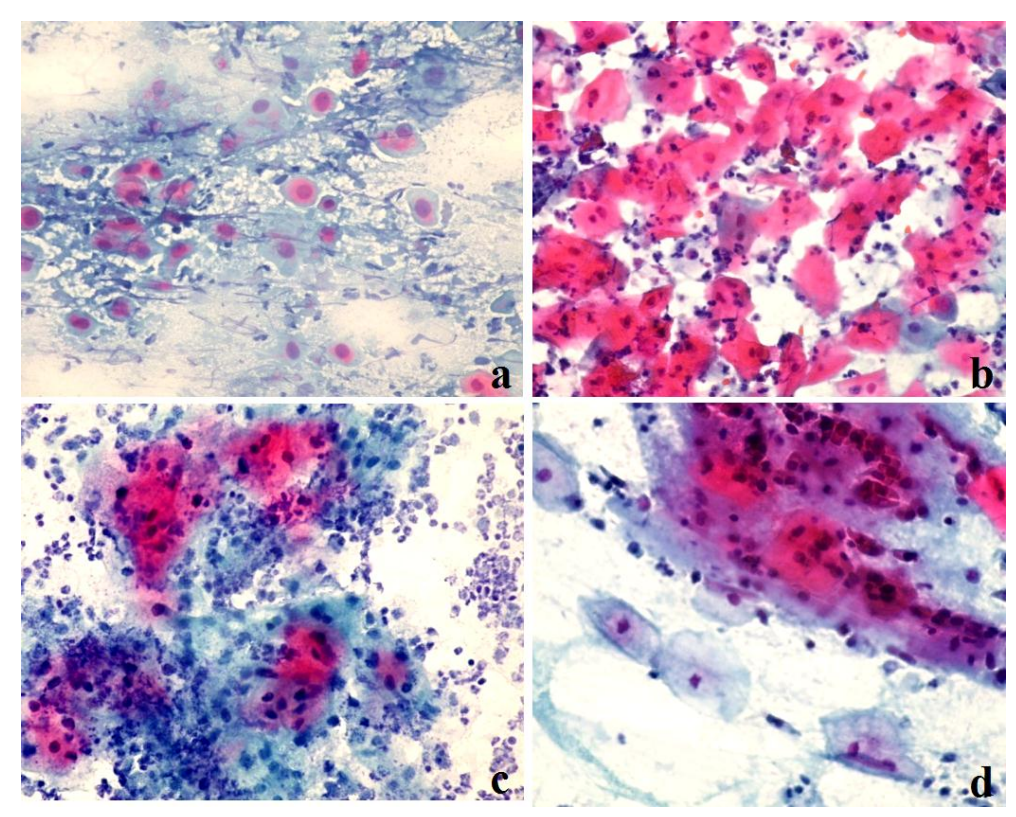

Figure 1 a. Atrophy findings (PAP, X400). b. Atypical squamous cells of undetermined significance (PAP, X400). c. Low-grade squamous intraepithelial neoplasia (PAP, X400). d. High-grade squamous intraepithelial neoplasia (PAP, X400).

\section{Discussion}

According to 2002 and 2005 researches, the highest incidence rates of cervical cancer are observed in sub-Saharan Africa, Melanesia, Latin America, the Caribbean, south central Asia, and Southeast Asia. Currently, the incidence rates in developed countries were generally low, with age-standardized rates less than 14.5/100 000. The incidence for Turkey is as low as 4.5/100 000 [2]. Also the studies made by the Turkish Ministry of Health, Department of Cancer Control in 2003 supported the rates reported for cervical cancer [3]. However, this pattern is relatively recent; before the introduction of screening programs in the 1960s and 1970s, the incidence rates in most of the European countries, North America, and Australia/New Zealand were similar to those in the developing countries today [6]. The incidence was 38.0/100 000 in the Second National Cancer 
Survey of the United States [7]. Also, very low rates are observed in China (6.8/100 000) and Western Asia (5.8/100 000); the lowest recorded rate is 0.4/100 000 in Ardabil, northwest Iran [8]. The major cause of cervical cancer is Human papilloma virus (HPV) are a large family of small double-stranded DNA viruses that infect squamous epithelia. Genital HPV infections are very common, sexually transmitted, and have peak prevalence between ages 18 and 30 years. The most important subtypes for cancer are HPV 16, found in 50 to $70 \%$ of cases, and HPV 18, found in 7 to $20 \%$ of cases [9]. This paper highlights the abnormalities seen in $\mathrm{CC}$ in the Turkish population in Çankırı. Up to a recent study, that was carried on the large amount of Turkish population, abnormal CC prevalence rate in Turkey is lower than that in India and Europe and North America [10]. They argue that, this might be due to sociocultural differences, lack of population-based studies or a lower HPV prevalence. The other cervical cancer risk factors are having first sexual intercourse before 16 years old, having more than four sexual partners, smoking, oral contraceptive use, and genital condyloma history [11]. One of the most important risk factor for cervical cancer is the absence of screening with the pap smear test which was first introduced in 1942 by Papanicolau. Cancer is more common among the women who do not have regular pap tests. SCC is seen 3.9 and 13 times more in a woman screened once in three years and 10 years, respectively, compared with ones screened annually [12]. In developed countries such as USA, 85\% of women had at least one pap test through their lifetime, but this rate is only 5\% in the developing countries [13]. American Cancer Society recommends initiating cervical cancer screening about 3 years after the first vaginal intercourse, but no later than 21 years old. Women who have had three normal Pap test results in a row may get screened every two to three years after their 30 s. Recommendations point that women at 70 years of age or older might choose to discontinue the screening with the Pap tests if they have had three or more normal Pap tests in a row and had no abnormal Pap test results in the last 10 years [14].

We demonstrated that 794 (8.8\%) of 8972 CC examinations were unsatisfactory. The main causes for CC inadequacy were sample obscured by red blood cells and inflammation. Previously, Beerman et al. [15] (0.89\%) found lower rates of unsatisfactory samples. Of all, 71 cases $(0.8 \%)$ were classified as ASCUS in this study. Recently, Davey et al. [16] reviewed 56 studies and found higher detection rates (3.8\%) of ASCUS with the CC examination. Moreover, Lawson et al. [17] found the ASCUS rate among lowincome women as 5.2\% and Remzi at al. [10] found the ASCUS rate as $1.9 \%$.On the other hand, Beerman et al. [15] (0.87\%) and Abdullah [18] (0.45\%) found lower detection rates of ASCUSIn the present study, the detection rates for ASCUS and over lesions were found to be $1.4 \%(n=129)$. There is different results from Turkey which were reported by Inal et al. [19] (0.7\%), Coskun et al. [20] (1.7\%), and Colgan et al. [21] in which the lesions rate were $3.8 \%$. Our results were significantly lower than those multi-centered studies reported from Europe and U.S.A (7\%-3.6\%) [22]. Turkish Cervical Cancer And Cervical Cytology Research Group (TCC and CCRG) published 140334 cervical smear results from 33 centers of Turkey in 2007 [23]. Overall, the prevalence of cervical cytological abnormalities was $1.8 \%$; the prevalence of preinvasive cervical neoplasia was $1.7 \%$ and the prevalence of cytologically diagnosed invasive neoplasia was $0.06 \%$. Our results were similar to TCC and CCRG and some other previous reports from Turkey [2325]. Previous foreign studies reported higher prevalence of ASC-US, LSIL, HSIL, and AGC in the USA $(3.9 \%, 2.1 \%, 0.5 \%$, and $0.2 \%$, respectively) [26]. Lower prevalence in our study compared with Christian countries may be due to the low prevalence of HPV, which might be a result of Islamic religion belief on sexual attitude and the conservative culture of population [25].

In conclusion, the prevalence of cervical cytological abnormalities in our study was $1.4 \%$. Recently, some conflicting results from the Turkish population were published. More studies with larger numbers are needed to determine the real prevalence of the cervical epithelial abnormalities in a Muslim country, to generate more reliable policies. 


\section{References}

1. Pisani P, Parkin DM, Bray F, Ferlay J. Estimates of the worldwide mortality from 25 cancers in 1990. Int J Cancer 1999; 83: 18-29.

2. Ferlay J, Bray F, Pisani P, Parkin DM. Cancer incidence, mortality and prevalence worldwide. Lyon, France: International agency for research on cancer (IARC); Cancer Base 2002.

3. Yılmaz HH, Yazıhan N, Tunca D, Sevinç A, Olcayto EÖ, Ozgül N, Tuncer M. Cancer trends and Incidence and mortality patterns in Turkey. Jpn J Clin Oncol 2011; 41: 10-6.

4. Karnon J, Peters J, Platt J, Chilcott J, McGoogan E, Brewer N. Liquid-based cytology in cervical screening: An updated rapid and systematic review and economic analysis. Health Technol Assess 2004; 8: iii, 1-78.

5. Boyle P, Ferlay J. Cancer incidence and mortality in Europe, 2004. Ann Oncol 2005; 16: 481-8.

6. Gustafsson L, Pontén J, Bergström R, Adami HO. International incidence rates of invasive cervical cancer before cytological screening. Int J Cancer 1997; 71: 15965.

7. Dorn HF, Cutler SJ. Morbidity from cancer in the United States. Public health monograph, Washington, DC: US Department of Health, Education, and Welfare; 1959.

8. Sadjadi A, Malekzadeh R, Derakhshan MH, Sepehr A, Nouraie M, Sotoudeh M, Yazdanbod A, Shokoohi B, Mashayekhi A, Arshi S, Majidpour A, Babaei M, Mosavi A, Mohagheghi MA, Alimohammadian M Cancer occurrence in Ardabil: results of a population-based cancer registry from Iran. Int J Cancer 2003; 107: 113-8.

9. Stanley M. Pathology and epidemiology of HPV infection in females. Gynecol Oncol 2010; 117: S5-10.

10. Atilgan R, Celik A, Boztosun A, Ilter E, Yalta T, Ozercan R. Evaluation of cervical cytological abnormalities in Turkish population. Indian $\mathrm{J}$ Pathol Microbiol 2012: 55; 52-5.

11. Kjellberg L, Hallmans G, Ahren AM, Johansson R, Bergman F, Wadell G, Angström T, Dillner J. Smoking, diet, pregnancy and oral contraceptive use as risk factors for cervical intra-epithelial neoplasia in relation to human papillomavirus infection. Br J Cancer 2000; 82: 1332-8.

12. IARC Monographs on the evaluation of carcinogenic risks humans. Human Papillomaviruses. Lyon: IARC; 2005 (Accessed on October 12, 2012).

13. Kuo DY, Goldberg GL. Screening of cervical cancer: Where do we go from here? Cancer Invest 2003; 21: 157-61.

14. www.cancer.org/.../FindCancerEarly/CancerScreeningGuidelines/americancance r- society-guidelines-for-the-early-detection-of-cancer (Accessed on October 12, 2012).

15. Beerman H, van Dorst EB, Kuenen-Boumeester V, Hogendoorn PC. Superior performance of liquid-based versus conventional cytology in a population-based cervical cancer screening program. Gynecol Oncol 2009; 112: 572-6.

16. Davey E, Barratt A, Irwig L, Chan SF, Macaskill P, Mannes P, Saville AM. Effect of study design and quality on unsatisfactory rates, cytology classifications, and accuracy in liquid-based versus conventional cervical cytology: A systematic review. Lancet 2006; 367: 122-32.

17. Lawson HW, Lee NC, Thames SF, Henson R, Miller DS. Cervical cancer screening among low-income women: Results of a national screening program, 1991-1995. Obstet Gynecol 1998; 92: 745-52.

18. Abdullah LS. Pattern of abnormal pap smears in developing countries: A report from a large referral hospital in Saudi Arabia using the revised 2001 Bethesda system. Ann Saudi Med 2007; 27: 268-72. 
19. Inal MM, Köse S, Yildirim Y, Ozdemir Y, Töz E, Ertopçu K, Ozelmas I, Tinar S. The relationship between human papillomavirus infection and cervical intraepithelial neoplasia in Turkish women. Int J Gyneacol Cancer 2007; 17: 1266-70.

20. Coskun A, Köstü B, Kiran G, Arikan DC, Analan A. Pap smear screening result in Kahramanmaras. Gynecol Obstet Reprod Med 2008; 14: 182-5.

21. Colgan TJ, McLachlin CM, Cotterchio M, Howlett R, Seidenfeld AM, Mai VM. Results of the implementation of liquid-based cytology-SurePath in the Ontario screening program. Cancer 2004; 102: 362-7.

22. Stany MP, Bidus MA, Reed EJ, Kaplan KJ, McHale MT, Rose GS, Elkas JC. The prevalence of HR-HPV DNA in ASC-US Pap smears: A military population study. Gynecol Oncol 2006; 101: 82-5.

23. Turkish Cervical Cancer and Cervical Cytology Research Group. Turkish Cervical Cancer and Cervical Cytology Research Group. Prevalence of cervical cytological abnormalities in Turkey. Int J Gyneacol Obstet 2009; 106: 206-9.

24. Karabulut A, Alan T, Ali Ekiz M, Iritaş A, Kesen Z, Yahşi S. Evaluation of cervical screening results in a population at normal risk. Int J Gyneacol Obstet 2010; 110: 40-2.

25. Celik C, Gezginç K, Toy H, Findik S, Yilmaz O. A comparison of liquid-based cytology with conventional cytology. Int J Gyneacol Obstet 2008; 100: 163-6.

26. National Cancer Institute, surveillance epidemiology and end results. Available from: http://seer.cancer.gov/statfacts/html/cervix.html (Accesed on December 4, 2012). 